\title{
ANALISIS TATA KELOLA (MANAJEMEN) PEMERINTAHAN DARI PERSPEKTIF GOOD GOVERNANCE
}

Oleh :

DR. A. Dirwan. M.Sc

\begin{abstract}
As stated in the preamble of the 1945 Constitution, the goal of our states is to form a government of the state of Indonesia which shall protect all the Indonesian people and the entire country, promote the general welfare, the intellectual life of the nation and participate in the establishment of world peace. This understanding is based on the need of clean government and to accommodate the principles of good governance. Currently, our government has not been fully able to protect and carry out its functions as mandated by the 1945 opening which is stated above. This is consistent with the results of research on Indonesia which governance has not improved significantly and has not been consistent after 15 years of reform. The data is processed by comparing the implementation of data governance at the beginning of the reforming process (1996/1998) and the 2009-2014 strategic plan (drawn from the data transparency of Worldwide Governance Indicators Projects 2010 and Kompas May 20, 2013).
\end{abstract}

Keywords; good governance, reform, improvement, consistent .

\begin{abstract}
Abstrak : Sebagaimana tertuang dalam Pembukaan UUD 1945 tujuan negara adalah membentuk suatu pemerintahan negara Indonesia yang melindungi segenap bangsa Indonesia dan seluruh tumpah darah Indonesia, memajukan kesejahteraan umum, mencerdaskan kehidupan berbangsa dan ikut melaksanakan ketertiban dunia. Perumusan tersebut dilatarbelakangi oleh sebuah pemahaman tentang perlunya pemerintahan negara Indonesia yang bersih dan memenuhi prinsip-prinsip Good Governance. Pemerintahan belum sepenuhnya mampu melindungi dan melaksanakan fungsinya sesuai yang diamanatkan oleh pembukaan UUD 1945 di atas. Hal ini sesuai dengan hasil penelitian tentang tata kelola pemerintahan Indonesia yang belum mengalami perbaikan signifikan dan belum konsisten setelah 15 tahun reformasi. Data diolah dengan membandingkan data implementasi tata kelola pemerintahan pada proses awal reformasi (1996/1998) dan Renstra 2009-2014 (disarikan dari data tranparency Worldwide Governance Indicators Projects 2010 dan Kompas 20 Mei 2013).
\end{abstract}

Kata kunci: good governance, reformasi, perbaikan yang signifikan, konsisten. 


\section{PENDAHULUAN}

Fenomena pada akhir-akhir ini semakin lunturnya pemahaman tentang semangat kebangsaan, menipisnya rasa nasionalisme dan patriotisme komponen bangsa, serta belum terciptanya pengelolaan pemerintahan yang baik, berpotensi menciptakan perpecahan, yang pada akhirnya luntur persatuan dan kesatuan bangsa.

Berdasarkan survei The Fund for Peace Washington DC., tentang Failed State Index, Mei 2012, Indonesia dinilai sebagai salah satu negara yang mengarah kepada negara gagal (Labolo 2012). Negara gagal adalah apabila tidak kapabel dalam penegakkan hukum, melindungi masyarakat, menjamin hak warga negara dan partisipasi politik, menjamin keamanan, memenuhi kebutuhan infrakstruktur serta berbagai fungsi sosial. Beberapa indikator yang dianggap Indonesia masih lemah adalah Demographic Pressure, Human Rights dan Group Grievance.

Tekanan demografis dapat dilihat pada seberapa jauh kemampan negara mengendalikan penduduk dan memproteksi dinamika warga negara. Dalam hal tekanan hak asasi manusia pada berbagai isu, seperti ideologi, sosial budaya, ekonomi, politik, hukum dan keamanan. Oleh karena itu diperlukan upaya meningkatkan pemahaman konsep pengelolaan negara dengan menciptakan Good Governance. Melalui partisipasi seluruh komponen bangsa, pengelolaan negara secara transparan dan tegaknya hukum akan meningkatkan sikap komponen bangsa terhadap persatuan dan kesatuan bangsa.

Sikap kepedulian, kesetaraan dan kebersamaan akan menumbuhkan rasa persatuan dalam mewujudkan tujuan negara. Di samping itu apabila manajemen negara dilaksanakan dengan visi yang tepat, efektif dan efisien, serta secara bertanggung jawab akan tercipta suatu dorongan dalam mewujudkan negara yang kuat jauh dari kegagalan.

Berbagai definisi perihal penyelenggaraan pemerintahan yang baik (good governance), untuk konteks Indonesia pada hakikatnya sebagaimana yang tercantum dalam Pembukaan UUD 1945: “...membentuk suatu pemerintahan negara Indonesia yang melindungi segenap bangsa Indonesia dan seluruh tumpah darah Indonesia, untuk memajukan kesejahteraan umum, mencerdaskan kehidupan bangsa, serta ikut melaksanakan ketertiban dunia yang berdasarkan kemerdekaan, perdamaian abadi dan keadilan sosial...".

Berdasarkan hal tersebut, ada empat point sebagai indikator umum bagi suatu tata pemerintahan Indonesia yang baik :

Pertama; Perlindungan yang maksimal terhadap warga negara, semangat nondiskriminasi atas segala kebijakan dan pelaksanaan pemerintahan.

Kedua; Memajukan kesejahteraan umum, kepentingan yang dijunjung oleh pemerintahan mestilah pararel dengan kepentingan rakyat, segala sumber daya yang dimiliki negara digunakan sebesarbesarnya bagi kemakmuran bersama.

Ketiga; Mencerdaskan kehidupan bangsa, pendidikan sebagai sarana untuk hadirnya kecerdasan bagi warga negara harus menjadi prioritas, pemerintah merespon setiap perubahan dan kebutuhan yang ada dalam masyarakat, terutama yang terkait dengan tranformasi ilmu pengetahuan dan keterbukaan informasi. 
Keempat; Hubungan internasional yang berprinsip pada kemerdekaan, perdamaian, dan keadilan sosial.

Pertanyaan yang timbul apakah negara telah mampu menjalankan fungsi-fungsi utamanya sebagaimana tertuang dalam pembukaan UUD 1945. Analisis singkat ini akan menguraikan bagaimana kondisi dan upaya pengelolaan negara berdasarkan pemahaman prinsip Good Governance, agar dapat menjaga eksistensi negara, serta dapat meningkatkan pengelolaan negara sesuai dengan yang diharapkan. Data diolah dengan membandingkan data implementasi tata kelola pemerintahan pada proses awal reformasi (1996/1998) dan data 15 tahun setelah reformasi ( disarikan dari data tranparency Worldwide Governance Indicators Projects 2010 dan Kompas 20 Mei 2013).

\section{KONSEP GOOD GOVERNANCE}

Pemerintah dalam arti paling dasar diterjemahkan sebagai sekumpulan orang yang memiliki mandat yang shah dari rakyat untuk menjalankan wewenangnya dalam urusan pemerintahan (Bappenas, 2002). Hubungan ini merupakan "kontrak sosial" antara rakyat sebagai pemberi mandat dan pemerintah sebagai pelaksana mandat. Beberapa hal yang terkandung dari makna "perintah", adanya "keharusan" yang menunjukkan kewajiban untuk melaksanakan apa yang diperintahkan dan hubungan fungsional antara yang memberi dan yang menerima perintah, serta wewenang untuk memberi perintah.

Sedangkan istilah governance lebih kompleks, karena menyangkut beberapa persyaratan yang terkandung dalam terminologinya. Komponen yang terlibat dalam governance, adalah pemerintah, dunia usaha (swasta) dan masyarakat pada umumnya termasuk partai politik. Good governance tidak mudah untuk didefinisikan secara seragam, karena istilah tersebut memiliki banyak makna yang bervariasi dan luasnya substansi bahasan. Keberagaman makna tersebut pada hakekatnya memiliki kesatuan tujuan yang utuh, yaitu pencapaian kondisi pemerintahan yang terselenggara secara seimbang dengan kerjasama semua komponen.

Kunci utama memahami Good Governance adalah pemahaman atas prinsip-prinsip yang ada di dalamnya. Bertolak dari prinsip-prinsip tersebut, akan didapatkan tolok ukur kinerja suatu pemerintahan. Baik buruknya pemerintahan bisa dinilai bila ia telah bersinggungan dengan semua unsur-unsur Good Governance. Prinsipprinsip Good Governance secara umum meliputi (UNDP, 1997) : Partisipasi Masyarakat, Tegaknya Supremasi Hukum, Transparansi, Responsif, Berorientasi pada Konsensus, Adil, Efektifitas dan Efisiensi, Akuntabilitas, dan Visi Strategis.

\section{a. Partisipasi Masyarakat.}

Warga masyarakat secara keseluruhan mempunyai suara dalam pengambilan keputusan, baik secara langsung maupun melaui lembaga perwakilan. Partisipasi menyeluruh tersebut dibangun berdasarkan kebebasan berkumpul dan mengungkapkan pendapat, serta kapasitas untuk berpartisipasi secara konstruktif. Partisipasi masyarakat mutlak diperlukan agar penyelenggaraan pemerintahan dapat mengenal masalah yang dihadapi, jalan keluar yang disarankan, serta apa yang dapat disumbangkan dalam memecahkan 
masalah tersebut. Keikutsertaan warga masyarakat dalam forum pertemuan publik, dan keaktifan mereka dalam menyumbangkan pikiran, menunjukkan bahwa urusan pemerintahan juga menjadi urusan mereka. Salah satu cara adalah memberi akses kepada wakil-wakil dari berbagai lapisan masyarakat untuk berpartisipasi menyuarakan kepentingan kelompok yang diwakilinya. Perwujudan dari prinsip tersebut adalah pembentukan forumforum pengambilan kebijakan publik yang memberi akses lebih besar kepada masyarakat untuk berpartisipasi.

\section{b. Tegaknya Supremasi Hukum.}

Kerangka hukum harus adil dan diperlakukan tanpa pandang bulu, termasuk di dalamnya hukum yang menyangkut hak asasi manusia. Dalam pemberian pelayanan publik dan pelaksanaan pembangunan seringkali terjadi pelanggaran hukum, seperti penyalahgunaan kekuasaan, dalam bentuk korupsi, kolusi dan nepotisme, serta pelanggaran HAM. Dalam hal ini, siapa saja yang melanggar harus diproses sesuai dengan ketentuan perundang-undangan yang berlaku. Prinsip supremasi hukum antara lain mencakup upaya pembentukan peraturan perundangan-undangan, pemberdayaan lembaga-lembaga penegak hukum, penuntasan kasus KKN dan pelanggaran HAM, peningkatan kesadaran hukum dan pengembangan budaya hukum.

\section{c. Transparansi.}

Transparansi dibangun atas dasar arus informasi yang bebas. Seluruh proses pemerintahan dan informasi dapat diakses oleh pihak-pihak yang berkepentingan dan informasi yang tersedia harus memadai agar dapat dimengerti dan dipantau. Semua urusan tata pemerintahan berupa kebijiakan-kebijakan publik yang berkenaan dengan pelayanan harus diketahui publik. Isi keputusan dan alasan pengambilan kebijakan, harus dapat diakses oleh publik dan harus diumumkan agar mendapat tanggapan. Aparat pemerintahan harus bersedia secara terbuka dan jujur memberikan informasi yang dibutuhkan publik.

\section{d. Responsif.}

Lembaga-lembaga dan seluruh proses pemerintahan harus berusaha melayani semua pihak yang berkepentingan. Dalam kehidupan sehari-hari, masyarakat atau sekelompok masyarakat tertentu menghadapi berbagai masalah dan krisis sebagai akibat dari perubahan situasi dan kondisi. Dalam situasi seperti ini, aparat pemerintahan tidak boleh masa bodoh tetapi harus cepat tanggap dengan mengambil prakarsa untuk memecahkan masalah-masalah tersebut. Aparat juga harus mengakomodasi aspirasi masyarakat sekaligus menindaklanjutinya dalam bentuk peraturan dan program yang diusulkan. Prinsip tata pemerintahan yang responsif antara lain adalah penyediaan pusat pelayanan bagi keluhan masyarakat dan pusat pelayanan masyarakat.

\section{e. Berorientasi pada Konsensus.}

Tata pemerintahan yang baik menjembatani kepentingan-kepentingan yang berbeda, demi terbangunnya suatu konsensus menyeluruh dalam hal apa yang terbaik bagi kelompok-kelompok masyarakat. Perumusan kebijakan 
tentang pelayanan publik dan pembangunan, dilakukan melalui mekanisme demokrasi, dan tidak ditentukan sendiri oleh eksekutif. Keputusan-keputusan yang diambil, baik oleh lembaga eksekutif maupun legislatif, harus didasarkan pada konsensus agar setiap kebijakan publik yang diambil benar-benar merupakan keputusan bersama.

\section{f. Adil.}

Semua warga masyarakat mempunyai kesempatan memperbaiki atau mempertahankan kesejahteraan mereka, berdasarkan kesetaraan. Instrumen dasarnya adalah peraturan perundang-undangan yang menjamin kesetaraan, dengan komitmen politik terhadap penegakkan hukum dan perlindungan HAM. Berkurangnya kasus diskriminasi, dan adanya kesetaraan jender, merupakan bagian dari keadilan. Adil merupakan karakteristik yang dapat mendorong akseptabilitas masyarakat pada pemerintahnya. Keadilan merupakan salah satu tujuan ingin dicapai oleh setiap pemerintah. Keadilan lazimnya melekat pada para pelaku pemerintahan, khususnya pemimpin. Keadilan bertujuan untuk menciptakan pemerataan termasuk memberikan hak dan kewajiban secara proporsional.

\section{g. Efektivitas dan Efisiensi.}

Proses pemerintahan dan lembagalembaga harus membuahkan hasil sesuai kebutuhan warga masyarakat dan dengan menggunakan sumber daya yang ada seoptimal mungkin. Agar dapat meningkatkan kinerja tata pemerintahan dibutuhkan dukungan struktur yang tepat. Oleh karena itu, pemerintahan dari waktu ke waktu harus selalu menilai dukungan struktur yang ada, melakukan perubahan struktural sesuai dengan tuntutan perubahan seperti menyusun kembali struktur kelembagaan secara keseluruhan dan menyusun jabatan dan fungsi yang lebih tepat. Di samping itu, pemerintahan yang ada juga harus selalu berupaya mencapai hasil yang optimal dengan memanfaatkan dana dan sumber daya lainnya yang tersedia secara efisien.

\section{h. Akuntabilitas.}

Para pengambil keputusan di pemerintah, sektor swasta dan organisasi-organisasi masyarakat bertanggung jawab, baik kepada masyarakat maupun kepada lembagalembaga yang berkepentingan. Penerapan prinsip akuntabilitas atau bertanggung jawab dalam penyelenggaraan pemerintahan diawali pada saat penyusunan program pembangunan (program accountability), pelaksanaan, dan penilaiannya (process accountability), sehingga program tersebut dapat memberikan hasil sesuai dengan tujuan yang ditetapkan (outcome accountability). Berdasarkan substansinya, prinsip bertanggungjawab mencakup akuntabilitas administratif, politik, profesional dan akuntabilitas moral (ethical accountability).

\section{i. Visi Strategis.}

Para pemimpin dan masyarakat memiliki perspektif yang luas dan jauh kedepan atas tata pemerintahan yang baik dan pembangunan manusia, serta kepekaan akan apa saja yang dibutuhkan untuk mewujudkan perkembangan tersebut. Semua kegiatan pemerintahan berupa pelayanan publik dan pembangunan 
seharusnya didasarkan pada visi dan misi tertentu disertai strategi implementasi yang jelas. Lembaga pemerintahan perlu memiliki rencana strategis (Renstra) sesuai dengan bidang tugas masing-masing sebagai pegangan dan arah pemerintahan di masa mendatang. Dengan demikian seluruh Program Pembangunan merupakan wujud dari prinsip tata pemerintahan yang berdasarkan visi strategis.

\section{METODOLOGI PENELITIAN}

Penelitian ini mempunyai tujuan untuk menganalisis permasalahan pengelolaan pemerintahan ditinjau dari sudut Good Governance. Untuk itu akan diteliliti perbedaan mean dan korelasi masalah tata kelola pemerintahan antara data pada awal proses reformasi (1996-1998) dan data Renstra 2009-2014, lebih kurang setelah 15 tahun reformasi.

Sumber data penelitian dari hasil jajak pendapat 579 responden yang diambil secara acak di 13 kota besar Indonesia pada bulan Mei 2013 (secondary data, Kompas 20 Mei 2013 dan Transparency Wordwide Governance Indicators Projects 2010). Indeks data implmentasi tata pemerintahan yang bergerak antara $-2,5$ sampai 2,5, diolah menjadi persentase dengan menggunakan distribusi normal. Misalnya untuk indeks $-2,5$, diperoleh luas curva normal 0,0062 atau sama dengan $0,62 \%$.

Untuk menghitung indeks secara keseluruhan digunakan curva dibawah ini.

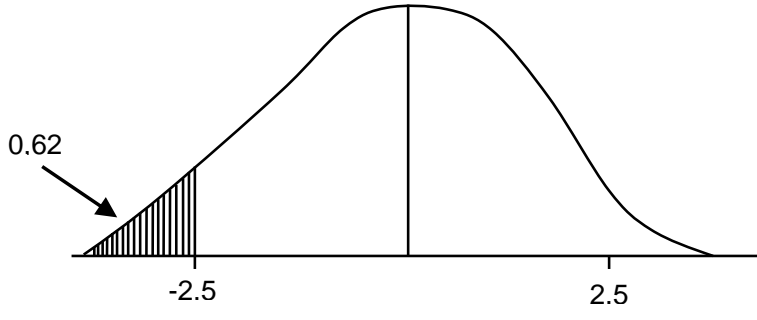

Curva Normal :

Perhitungan Indeks Implementasi Tata Pemerintahan

Metoda menggunakan tehnik studi kepustakaan dan tehnik perbedaan mean dan korelasional untuk melihat sejauh mana perbedaan penerapan good governance pada awal proses reformasi dan pada Renstra 2009-2014. Apabila perbedaan mean signifikan (setelah reformasi mean lebih tinggi) dan korelasi tinggi berarti implementasi good governance membaik dan adanya konsistensi dalam mengatasi masalah-masalah yang berhubungan dengan tata pemerintahan. Tehnik analisis data digunakan untuk menguji hipotesis penelitian semakin membaiknya tata kelola pemerintahan setelah reformasi.

Dari analisis data diperoleh perbedaan mean tidak signifikan $\left(\mathrm{t}_{\text {(selisih tiap pasang) }}=\right.$ 0,0018 lebih kecil dari $\left.t_{0,95(8)}=1,86\right)$. Koefisian korelasi sebesar $r=0,139$, sangat tidak signifikan setelah diadakan uji $\mathrm{t}\left(\mathrm{t}_{\mathrm{r}=0,139(9)}=0,37\right.$ lebih kecil dari $\mathrm{t}_{0,975(7)}=$ 2,36). Kesimpulan belum ada perbedaan yang signifikan (membaik) dan belum ada konsistensi mengarah kepada yang lebih diharapkan dalam pengelolaan pemerintahan setelah reformasi. 
Tabel : Indeks Implementasi Tata Kelola Pemerintahan Indonesia

\begin{tabular}{|c|c|c|c|c|c|c|}
\hline \multirow[b]{2}{*}{ NO } & \multirow[b]{2}{*}{ ASPEK } & \multicolumn{2}{|c|}{ INDEKS } & \multicolumn{2}{|c|}{ PERSENTASE (DIOLAH) } & \multirow[b]{2}{*}{ KETRGN } \\
\hline & & $\begin{array}{c}\text { AWAL } \\
\text { PROSES } \\
\text { REFORMASI }\end{array}$ & $\begin{array}{l}\text { RENSTRA } \\
2009-2014\end{array}$ & $\begin{array}{l}\text { AWAL PROSES } \\
\text { REFORMASI }\end{array}$ & $\begin{array}{l}\text { RENSTRA } \\
2009-2014\end{array}$ & \\
\hline 1 & INDEK PERSEPSI KORUPSI & 27,2 & 32 & 27,2 & 32 & $\begin{array}{c}\text { RENTANG } \\
0-100\end{array}$ \\
\hline 2 & $\begin{array}{l}\text { KETERWAKILAN DAN } \\
\text { AKUNTABILITAS }\end{array}$ & $-1,17(1996)$ & $\begin{array}{c}-0,15 \\
(2009)\end{array}$ & 12,1 & 48,01 & \multirow{6}{*}{$\begin{array}{l}\text { RENTANG } \\
-25-2,5\end{array}$} \\
\hline 3 & $\begin{array}{l}\text { STABILITAS POLITIK DAN } \\
\text { KETIADAAN KEKERASAN }\end{array}$ & $-1,03(1996)$ & $\begin{array}{c}0,64 \\
(2009)\end{array}$ & 15,15 & 75,89 & \\
\hline 4 & $\begin{array}{l}\text { EFEKTIFITAS } \\
\text { PEMERINTAH }\end{array}$ & 0,197 (1996) & $\begin{array}{l}-0,21 \\
(2009)\end{array}$ & 97,59 & 41,68 & \\
\hline 5 & KUALITAS REGULASI & 0,398 (1996) & $\begin{array}{l}-0,28 \\
(2009)\end{array}$ & 65,17 & 38,97 & \\
\hline 6 & PENEGAKAN HUKUM & $-0,27(1996)$ & $\begin{array}{l}-0,56 \\
(2009)\end{array}$ & 39,36 & 27,77 & \\
\hline 7 & $\begin{array}{l}\text { PEMBERANTASAN } \\
\text { KORUPSI }\end{array}$ & $-0,34(1996)$ & $\begin{array}{l}-0,71 \\
(2009)\end{array}$ & 36,69 & 23,88 & \\
\hline 8 & KEBEBASAN BERPOLITIK & 70,1 & 76,1 & 70,10 & 76,10 & \multirow[b]{2}{*}{$\begin{array}{l}\text { RENTANG } \\
0-100\end{array}$} \\
\hline 9 & KEBEBASAN BEREKSPRESI & 71,5 & 77,5 & 71,5 & 77,5 & \\
\hline
\end{tabular}

Sumber : Transparency Worldwide Governance Indicators Projects 2010 dan Kompas, 20 Mei 2013, Halaman 1. 


\section{HASIL dan PEMBAHASAN}

Sebagai sistem organisasi, pemerintah tidak hanya memberi jaminan terhadap semua upaya kearah realisasi visi dan misinya, tetapi juga secara langsung menyentuh kepentingan masyarakat dalam bentuk pelayanan. Dalam kenyataan bagaimana mungkin pemerintah dapat melayani masyarakat dengan penuh kejujuran dan keikhlasan jika beban yang ditanggung melebihi kapasitasnya sendiri. Apabila pemerintah berupaya bagaimana menyelesaikan problem ditengah-tengah masyarakat, maka pemerintah harus lebih dulu berkeringat untuk menyelesaikan alat pembersih (birokrasi) sebelum berharap banyak akan berkurangnya masalah yang dihadapi masyarakat. Misalnya sumber daya nasional hanya dimanfaatkan oleh kelompok tertentu, akibatnya tumbuh kecemburuan sosial antar kelompok masyarakat yang mengancam kesatuan dan persatuan nasional.

Good governance merupakan indikator perbaikan manajemen pemerintahan di tengah-tengah munculnya berbagai permasalahan ekonomi dan politik yang dihadapi Indonesia. Berbagai kasus pelanggaran hukum, norma-norma dan etika yang muncul di permukaan belum mendapatkan solusi hukum yang memuaskan masyarakat.

Berbagai kebijakan pemerintah yang tidak populer terhadap masalah ekonomi telah menjadi isu politik dan sosial yang melibatkan pemerintah sebagai sasaran "tembak". Berbagai protes dan demo dilaksanakan untuk menentang kebijakan yang tidak populer tersebut, sehingga berdampak terhadap semakin buruknya popularitas dan citra pemerintah. Pemberantasan KKN yang menjadi tujuan gerakan reformasi di bawah pola pemerintahan yang bersih belum mampu dilaksanakan sesuai dengan harapan masyarakat. Keprihatinan yang sangat mendalam telah muncul dalam bentuk berbagai kritik masyarakat Indonesia terhadap pemerintahan saat ini, karena kondisi Indonesia pasca krisis dirasakan semakin memburuk atau mengarah kepada negara gagal.

Salah satu penyebab krisis moneter dan ekonomi di beberapa negara Asia pada tahun 1997/1998 adalah kualitas pemerintahan yang buruk (Husnan, 2000). Tata kelola berfungsi untuk menjalankan setiap sistem yang telah dipilih dengan tingkat akurasi dan konsistensi yang tinggi, sehingga terhindar dari moral hazard, perburuan rente, dan korupsi. Kebijakan ekonomi di Indonesia berantakan begitu dijalankan karena rapuhnya tata kelola pemerintahan. Kepastian regulasi juga bermasalah karena dibuat secara serampangan sehingga mudah sekali dipatahkan di Makamah Konstitusi (jika berupa UU) ataupun berubah karena tidak sesuai dengan kebutuhan dilapangan. Selanjutnya masing-masing prinsip Good Governance dianalisis sebagai berikut :

\section{a. Partispasi.}

Alienasi politik menyebabkan sukarnya mendorong partisipasi politik yang lebih tinggi dan konstruktif. Penelitian Templeton (1966) menunjukkan hubungan yang sangat kuat antara alienasi politik dan tingkat partisipasi politik. Kondisi alienasi politik yang tinggi cenderung mengakibatkan penarikan diri (withdrawal) terhadap aktivitas politik nasional.

Partisipasi masyarakat dapat terwujud seiring dengan tumbuhnya rasa percaya msyarakat kepada para penyelenggara pemerintahan. Rasa percaya ini akan tumbuh apabila masyarakat 
memperoleh pelayanan dan kesempatan yang setara (equal). Tidak boleh ada perlakuan atas dasar apapun dapat menumbuhkan kecemburuan dan mendorong terjadinya konflik sosial masyarakat. Hasil data penelitian dari sisi keterwakilan sudah meningkat dari $12 \%$ menjadi $48 \%$, namun kebebasan berpolitik dan berekspresi hanya meningkat $6 \%$.

Untuk itu masih perlu didorong agar setiap warga mempergunakan hak dalam menyampaikan pendapat dalam proses pengambilan keputusan, yang menyangkut kepentingan masyarakat, baik secara langsung maupun tidak langsung. Partisipasi bermaksud untuk menjamin agar setiap kebijakan yang diambil mencerminkan aspirasi masyarakat. Dalam rangka mengantisipasi berbagai isu yang ada, pemerintah menyediakan saluran komunikasi agar masyarakat dapat mengutarakan pendapatnya.

Meningkatnya kepercayaan masyarakat kepada pemerintah, meningkatnya jumlah masyarakat yang berpartisipasi dalam pembangunan, meningkatnya kuantitas dan kualitas masukan (kritik dan saran) untuk pembangunan dan terjadinya perubahan sikap masyarakat menjadi lebih peduli terhadap setiap langkah pembangunan. Partisipasi aktif masyarakat lebih jauh menggambarkan sejauh mana kepentingan mereka telah terakomodir dengan baik selain melibatkan mereka dalam hal tanggung jawab yang lebih luas.

Rendahnya partisipasi masyarakat dalam pengelolaan pemerintahan, disebabkan oleh rendahnya kesadaran masyarakat tentang pentingnya partisipasi dalam pembangunan. Di lain pihak, masyarakat yang seharusnya mampu menjadi pengamat dan penasihat pemerintah dalam menjalankan strategi yang lebih baik, ternyata masih belum memiliki kemampuan dan pengalaman partisipasi yang cukup dalam pengambilan kebijakan publik. Hal ini berujung pada kondisi sosio-politik negara yang semakin tidak menentu. Keadaan tersebut tidak hanya mengganggu stabilitas keamanan nasional, tetapi lebih jauh lagi ikut menghambat perkembangan perekonomian negara.

\section{b. Penegakkan Hukum.}

Mewujudkan penegakan hukum yang adil bagi semua pihak tanpa pengecualian, menjunjung tinggi HAM dan memperhatikan nilai-nilai yang hidup dalam masyarakat. Berdasarkan kewenangannya, pemerintah harus mendukung tegaknya supremasi hukum dengan melakukan berbagai penyuluhan peraturan prundangundangan dan menghidupkan kembali nilai-nilai dan norma-norma yang berlaku di masyarakat.

Hasil penelitian ini, karena banyaknya peraktek korupsi menyebabkan indeks persepsi terhadap korupsi masih belum memamadai (32 \%) dan persentase penegakkan hukum turun dari $39 \%$ menjadi $27 \%$. Instrumen dasar penegakkan hukum adalah peraturan perundang-undangan, komitmen politik terhadap penegakkan hukum dan keterpaduan dari sistem yuridis (kepolisian, pengadilan dan kejaksaan).

Kenyataan belum berkurangnya praktek KKN dan pelanggaran hukum, lambatnya proses penegakkan hukum, dan kurangnya kepercayaan 
masyarakat pada aparat penegak hukum. Pembangunan yang selama ini dilakukan di Indonesia kurang intens menerapkan pola-pola dasar dalam pemerintahan yang baik. Ketaatan hukum memberikan landasan bagi pemerintah dalam menjalankan visi dan misi yang di emban sekaligus memperlihatkan tingkat akseptabilitas masyarakat terhadap pemerintah. Dalam hubungan tersebut dibutuhkan kesadaran pemimpin untuk memberikan contoh sehingga mampu mendorong terwujudnya tertib hukum.

\section{c. Transparansi.}

Transparansi diperlukan untuk menciptakan kepercayaan timbal balik antara pemerintah dan masyarakat melalui penyediaan informasi yang akurat dan memadai. Berkaitan dengan hal tersebut pemerintah perlu proaktif memberikan informasi lengkap tentang kebijakan dan layanan yang disediakannya kepada masyarakat. Menurut penelitian ini salah satu aspek transparansi adalah kebebasan berpolitik dan berekspresi, belum menunjukan peningkatan yang signifikan (hanya naik $6 \%$ ).

KKN adalah salah satu sifat eksklusif yang mempersulit terciptanya Good governance, karena kelompok yang memperaktekan KKN cendrung tertutup, serta tidak mudah dimonitor dan diawasi. Ketertutupan sudah bertentangan dengan prinsip equal opportunity untuk melakukan partisipasi politik secara terbuka. Ditambah lagi peran-peran tertentu dalam pemerintahan sudah diblokir oleh grupgrup yang menikmati hak-hak istimewa. Regulasi dan praktek pengelolaan pemerintahan yang tidak menerapkan aspek keterbukaan, niscaya merupakan tantangan utama untuk terwujudnya good governance. Isu keterbukaan yang merupakan prasyarat bagi adanya akuntabilitas publik selayaknya menjadi modus operandi untuk mencapai demokrasi yang substansial. Tanpa adanya keterbukaan dalam proses pengelolaan pemerintahan, termasuk melawan korupsi, maka segala upaya yang akan dilakukan hanya menjadi angin lalu dan akan mati dengan sendirinya.

Transparansi merupakan karakteristik yang memungkinkan terbangunnya kepercayaan masyarakat terhadap pemerintah, terutama dalam hal kepentingan dan kebutuhan masyarakat. Rendahnya transparansi pemerintah berkenaan dengan perencanaan dan implementasi kebijakan, telah menunjukkan lemahnya itikad baik dalam mewujudkan harapan masyarakat.

\section{d. Responsif.}

Responsif di tandai meningkatnya kepekaan para penyelenggara pemerintahan terhadap aspirasi masyarakat, tanpa kecuali. Hal ini akan terlihat dari meningkatnya kepercayaan masyarakat pada pemerintah, tumbuh dan meningkatnya kesadaran masyarakat yang berpartisipasi dalam pembangunan.

Kurangnya rensponsif akan menimbulkan alienasi politik sebagai suatu bentuk kehilangan keterhubungan (loss of a relationship), kehilangan partisipatif (loss of participation) dan kehilangan kemampuan mengendalikan (loss of control) dalam kehidupan sosial masyarakat (Yinger, 1973). Responsif pemerintah dapat dilihat juga dari kesungguhan pemerintah memberantas 
korupsi, yang dalam peneletian ini upaya pemberantasan korupsi turun drastis menjadi $23 \%$. Salah satu wujud dari responsif adanya kepekaan (daya tanggap) dari pemerintah dan para politisi di lembaga legislatif dalam mengkaji berbagai kebutuhan masyarakat. Sebaliknya masyarakat juga dituntut mempunyai daya-tanggap yang tinggi dalam memantau berbagai tindakan kepemerintahan.

Responsif adalah karakteristik pemerintah yang mampu memberikan tanggapan sedini mungkin terhadap setiap masalah yang dihadapi masyarakat. Kemampuan memberikan jawaban atas setiap masalah yang dihadapi masyarakat menunjukkan kemampuan pemerintah dalam memahami apa yang menjadi kebutuhan utama masyarakat. Kegagalan merespons setiap masalah yang dihadapi masyarakat selama ini, menunjukkan ketidakpedulian pemerintah serta hilangnya self of belonging atas problem yang dialami oleh masyarakat. Dalam kenyataan, jangankan kehadiran, pernyataan pemerintahpun tidak dapat dinilai sebagai respons positif terhadap masalah yang sedang mereka hadapi.

\section{e. Konsensus.}

Karakteristik yang menggambarkan kemampuan pemerintah dalam membangun kesepakatan antara tuntutan secara bottom-up dan top-down merupakan bentuk konsensus. Konsensus juga merujuk pada bagaimana pemerintah membangun kesepahaman yang memungkinkan semua kepentingan dapat diakomodir pada saluran yang tersedia. Konsensus bersama yang dibangun selama ini, baru menyangkut nasib elit partai dalam kualisi. Pola yang ditata dalam logika-logika demokrasi, seperti terselenggaranya pemilu yang sehat untuk memastikan hak politik setiap warga negara tak terbajak oligarki dan proses pengambilan keputusan yang partisipatif melalui mekanisme bottomup, belum sepenuhnya terwujud.

Hasilnya elite yang muncul akan bernasib kesepian karena dirinya tak merefleksikan kepentingan partai dan tak membangun jawaban atas kebutuhan rakyat. Parpol kini dinilai hanya memperjuangkan kepentingan elite politiknya dan mengembangkan kepentingan konstituen. Citra dan rapor kinerja parpol nyaris senantiasa terpuruk dari waktu ke waktu. Dari hasil penelitian dalam kebebasan berpolitik dan berekspresi belum mengalami kenaikan yang berarti ( hanya $6 \%$ \%). Kegagalan dalam membangun konsensus dapat meruntuhkan kepercayaan masyarakat dimana pemerintah dapat dinilai mengkhianati amanah yang diberikan.

\section{f. Adil.}

Adil merupakan upaya memberi peluang yang sama bagi setiap anggota masyarakat untuk meningkatkan kesejahteraannya. Tujuan dari prinsip tersebut untuk menjamin agar kepentingan pihak-pihak yang kurang beruntung, seperti mereka yang miskin dan lemah, tetap terakomodasi dalam proses pengambilan keputusan.

Dalam suatu organisasi nepotisme merupakan hal yang menyimpang, termasuk mempekerjakan saudarasaudara seorang pejabat di kantornya, sekalipun mereka terbukti sanggup. Kalau mereka sudah melewati semua 
tes seleksi dengan benar dan lulus, mengapa mereka tidak boleh mendapat pekerjaan dan posisi yang mereka kehendaki. Melarang mereka bekerja dari sisi keadilan, hanya karena mereka sanak dan kerabat pejabat tersebut, merupakan suatu diskriminasi. Selayaknya mereka diterima sampai terbukti bahwa hubungan kekeluargaan membuat mereka melakukan penyimpangan dalam tugas, atau tidak bekerja dengan efektif sesuai tuntutan tugas.

Dalam hal ini yang perlu dilakukan adalah mencegah kemungkinan dan memperkecil kesempatan untuk melakukan penyimpangan. Dengan demikian yang harus berlaku dalam organisasi bukanlah asas praduga tak bersalah (presumption of innocence), tetapi asas praduga kemungkinan jatuhnya seseorang dalam kelemahan dan kesalahan (presumption of fallibility), karena ketiadaan kontrol. Dari hasil penelitian dalam kontek keadilan, stabilitas politik dan ketiadaan kekerasan sudah baik (75\%), namun keadilan dalam penegakkan hukum sangat memprihatinkan (27\%). Berlaku adil merupakan karakteristik yang dapat mendorong akseptabilitas masyarakat pada pemerintahnya.

\section{g. Efisien dan Efektif.}

Berbagai sumberdaya pemerintahan bersifat terbatas, sementara kebutuhan masyarakat sangat beraneka ragam dan relatif tak terbatas. Dari hasil penelitian, efektivitas pemerintah menurun dari $97 \%$ sebelum reformasi, menjadi $41 \%$ setelah reformasi.

Dengan demikian pihak-pihak yang terkait dengan tata pemerintahan harus mempunyai kesadaran untuk bersikap efisien dan efektif. Efisiensi dan efektivitas menjamin terselenggaranya pelayanan kepada masyarakat dengan menggunakan sumberdaya yang tersedia secara optimal dan bertanggung jawab. Pelayanan masyarakat belum mengutamakan kepuasan masyarakat, dan belum didukung mekanisme penganggaran serta pengawasan yang rasional dan transparan.

Efisiensi dan efektivitas merupakan karakteristik good governance yang merefleksikan kemampuan pemerintah dalam pencapaian tujuan secara tepat guna dan hasil guna. Pencapaian tujuan dengan mempertimbangkan aspek efisiensi dan efektivitas dapat mendorong produktivitas pemerintahan menjadi lebih berkualitas tanpa membuang modal yang ada. Kegagalan pemerintah dalam mempertimbangkan efisiensi dan efektivitas membuat pemerintah kehilangan modal yang besar.

\section{h. Akuntabilitas.}

Sebagai konsekuensi dari pemberian hak dan kewenangan, penyelenggara pemerintahan dituntut melaksanakan tugas dan kewajiban secara profesional. Dari hasil penelitian persentase akuntabilitas sudah naik cukup tajam dari sebelum reformasi, namun persentase tersebut masih relatif rendah (48\%).

Dalam menjalankan tugas dan kewajibannya penyelenggara pemerintahan harus sadar untuk tidak hanya berorientasi pada hasil tetapi juga pada kebenaran dan kewajaran dalam proses pencapaiannya. Pembuat kebijakan pada semua tingkatan belum memahami bahwa mereka harus 
mempertanggung jawabkan hasil kerja kepada masyarakat, hal ini terlihat dari indeks persepsi korupsi masih rendah (32\%). Akuntabilitas akan meningkatkan kepercayaan dan kepuasan masyarakat terhadap pemerintah, tumbuhnya kesadaran masyarakat, meningkatnya keterwakilan berdasarkan pilihan dan kepentingan masyarakat, dan berkurangnya kasus-kasus KKN.

Di dalam pemerintahan yang demokratis, segala hal yang dikerjakan pemerintah harus bisa dipertanggungjawabkan kepada publik. Salah satu faktor mengapa pemerintah selama ini terkesan mandul dalam menjawab setiap problem masyarakat, karena tingginya kepentingan pribadi dan selalu memikirkan seberapa banyak kekayaan yang dapat dikumpulkan pasca suatu jabatan.

Sering terjadi transaksi illegal untuk mengeruk keuntungan sebanyak mungkin, dalam bentuk kesepakatan diluar aturan yang semestinya. Meletakkan tanggung jawab satusatunya pada sektor pemerintah bukanlah gagasan ideal untuk menciptakan pemerintahan yang baik. Tanggung jawab merupakan nilai yang mampu menjembatani relasi antara pemerintah dan masyarakat untuk menjamin kelangsungan pemerintahan.

Tanggung jawab pada elemen masyarakat dibutuhkan agar masyarakat sadar akan output yang diberikan pemerintah dan memelihara semua produk pelayanan yang diberikan, serta ikut bertanggung jawab terhadap kegagalan pemerintah yang dipilih oleh mereka sendiri.

\section{i. Visi Strategis.}

Pembangunan harus berdasarkan visi dan strategi yang jelas, serta mengikutsertakan warga dalam seluruh prosesnya, sehingga warga merasa memiliki dan ikut bertanggung jawab terhadap kemajuan negaranya. Tujuan penyusunan visi adalah untuk memberikan arah pembangunan secara umum sehingga dapat membantu dalam penggunaan sumber daya secara efektif.

Untuk mendapatkan visi yang dapat diterima secara luas, visi tersebut perlu disusun secara terbuka dan transparan, serta didukung oleh partisipasi kelompok masyarakat. Hal ini belum sepenuhnya dilakukan, terlihat berganti pemerintah berganti pula visi. Kualitas regulasi dan pemberantasan korupsi, merupakan penjelmaan visi kedepan, persentase kedua hal ini relatif rendah (38\% dan $23 \%$ ). Tidak jelasnya visi dan strategi akan memberikan kegamangan dalam menyusun kebijakan perencanaan dan program, yang pada gilirannya akan mendorong timbul sikap tertutup dan ekslusif aparat pemerintah terhadap keterlibatan masyarakat.

Visi strategis membutuhkan kesinambungan dalam mengawal agenda-agenda yang telah ditetapkan. Pemerintahan yang bertolak dari visi adalah pemerintahan yang mempunyai pandangan jauh kedepan, serta memiliki cita-cita yang bersifat jangka panjang dan berkelanjutan. 


\section{PENUTUP}

Sebagai penutup dari tulisan ini, disampaikan beberapa hal :

a. Pembukaan UUD 1945, mengamanatkan pemahaman tentang perlunya pemerintahan negara Indonesia yang bersih dan memenuhi prinsip-prinsip Good Governance. Pemerintahan belum sepenuhnya mampu melindungi dan melaksanakan fungsinya sesuai yang diamanatkan oleh pembukaan UUD 1945 di atas. Hal ini sesuai dengan hasil penelitian tentang tata kelola pemerintahan Indonesia yang belum mengalami perbaikan signifikan dan belum konsisten setelah 15 tahun reformasi.

b. Perlu kemaun dari seluruh komponen bangsa, terutama para pemimpinnya, untuk mengimplementasikan konsep Good Governance dalam dinamika kehidupan bangsa secara menyeluruh. Di samping itu diperlukan juga kesadaran dari semua lapisan masyarakat untuk berkerjasama dengan pemerintah dalam memacu langkah dan upaya pemahaman tersebut. Seiring dengan proses demokratisasi yang terus berjalan, akan berdampak pada makin meningkatnya tuntutan akan partisipasi masyarakat dalam kebijakan publik. Dengan demikian tuntutan penerapan prinsip-prinsip tata kepemerintahan yang baik merupakan keharusan.

c. Implikasi. Beberapa hal yang dapat dikemukan sebagai implikasi :

Pertama ; hambatan yang ditemui pada pelaksanaan good governance di Indonesia harus dihilangkan, seperti kondisi sosio-politik yang diwarnai oleh tingkat korupsi yang tinggi dan kekuatan menekan dari masyarakat yang masih lemah. Pemerintahan tidak dijalankan oleh kekuatan politik oligarki, karena tanpa disadari politik oligarki akan mengakibatkan terhambatnya proses reformasi, baik dalam bidang politik, hukum, maupun ekonomi, yang berujung pada ketidakberhasilan penciptaan struktur politik dan ekonomi.

Kedua; Pemerintahan harus dapat menjamin kepentingan publik secara seimbang dengan melibatkan kerjasama antara semua komponen bangsa (negara, masyarakat, dan pihak swasta). Melalui proses tersebut diharapkan akan tumbuh konsensus dan sinergi dalam penerapan program - program tata kepemerintahan yang baik di masyarakat. Pelaku-pelaku tersebut masing-masing memiliki karakter tersendiri tetapi ketiganya tidak akan mampu berdiri dan berkembang sendiri-sendiri untuk mencapai kehidupan yang lebih baik bagi setiap lapisan masyarakat.

Ketiga; mewujudkan tata kelola pemerintahan yang bersih, efisien dan efektif, serta menumbuhkan suasana politik yang demokratis melalui keterbukaan, tanggung jawab, tanggap akan aspirasi rakyat, menghargai perbedaan, dan jujur dalam persaingan.

Keempat; menumbuhkan kesadaran bahwa tertib sosial, ketenangan dan keteraturan hidup bersama, hanya dapat diwujudkan dengan ketaatan terhadap hukum dan peraturan perundangan yang berpihak kepada keadilan, menghindarkan penggunaan hukum sebagai alat kekuasaan, serta bentuk-bentuk manipulasi hukum lainnya.

d. Sebagai bagian akhir dari tulisan ini, disarankan setiap pemimpin dalam pemerintahan dapat memberikan contoh yang baik, sesuai kata dengan perbuatan, dan jujur kepada diri sendiri maupun orang lain.

Demikianlah tulisan singkat ini disampaikan, mudah-mudahan ada manfaatnya dalam membangun bangsa yang tercinta ini. 


\section{DAFTAR PUSTAKA}

1. Bappenas. Public Good Governance. Jakarta, 2002.

2. Griffin, Ricky W. Management. U.S.A: Houghton Mifflin Company, 1997.

3. Kemenko Polhukam. Wawasan Kebangsaan. Jakarta, 2008.

4. Labalo, M. Memperkuat Pemerintahan mencegah Negara Gagal. Jakarta:

Kubah Ilmu, 2012.

5. Max Weber dalam Martin Albrow (terjemahan). Birokrasi. Yogyakarta : Tiara Wacana, 1996.

6. Sudjana. Metoda Statistika. Bandung : Tarsito, 2005.

7. Stoner, James A.F. Management. New Jersey: Prentice Hall, Inc., 1994.

8. Undang-undang RI Nomor 28/1999. Penyelenggaraan Negara yang Bersih dan Berwibawa. Jakarta, 1999.

9. UNDP. Human Development Report. Washington D.C., 2013. 